KatARZYNA ZAMBRZYCKA-PAPUDA

Cardinal Stefan Wyszyński University

in Warsaw, Poland

\title{
THE ELECTION CAMPAIGN FOR THE OFFICE OF THE MAYOR OF WARSAW IN THE 2018 LOCAL GOVERNMENT ELECTIONS IN THE CONTEXT OF E. GOFFMAN'S DRAMATIC THEORY, ON THE EXAMPLE OF CANDIDATES FROM PATRYK JAKI AND RAfal TRZASKOWSKI
}

KAMPANIA WYBORCZA NA URZĄD PREZYDENTA WARSZAWY W WYBORACH SAMORZĄDOWYCH 2018 ROKU W KONTEKŚCIE TEORII DRAMATURGICZNEJ ERVINGA GOFFMANA, NA PRZYKŁADZIE KANDYDATÓW Patryka Jakiego i Rafala Trzaskowskiego

\begin{abstract}
E. Goffman's theory of everyday life assumes that a person plays many roles in his life. Each of them is matched by appropriate behavior, appearance or even used vocabulary. In line with these assumptions, a politician is also an actor with a clearly defined scenario and wanting to have a specific effect in the perception of the audience. Knowledge and image-building tools are used to achieve this goal. The following work will analyze the content of selected aspects of the election campaign for the office of the Mayor of Warsaw in the local elections in 2018. The fight for voters' votes between Patryk Jaki and Rafał Trzaskowski will be illustrated, with the specification of the image creation tools used by both politicians.
\end{abstract}




\section{STRESZCZENIE}

Teoria życia codziennego Ervinga Goffmana zakłada, że człowiek odgrywa w swoim życiu wiele ról. Do każdej z nich dopasowuje odpowiednie zachowanie, wygląd czy nawet używane słownictwo. Zgodnie z tymi założeniami również polityk jest aktorem posiadającym wyraźnie sprecyzowany scenariusz i chcącym wywołać określony efekt w odbiorze widowni. Do osiągnięcia tego celu wykorzystywane są wiedza i narzędzia $\mathrm{z}$ zakresu kreowania wizerunku. W poniższej pracy dokonana zostanie analiza treści wybranych aspektów kampanii wyborczej na urząd prezydenta Warszawy w wyborach samorządowych w $2018 \mathrm{r}$. Zobrazowana zostanie walka o głosy wyborców tocząca się pomiędzy Patrykiem Jakim a Rafałem Trzaskowskim z wyszczególnieniem zastosowanych przez obu polityków narzędzi kreowania wizerunku.

KEYWORDS: election campaign, image building, mass media, social role, dramaturgical theory.

SŁOWA KLUCZOWE: kampania wyborcza, kreowanie wizerunku, media masowe, rola społeczna.

\section{WPROWADZENIE. SCENA POLITYCZNA JAKO TEATR}

Życie społeczne i wszystkie jego aspekty według Ervinga Goffmana są częścią teatru życia codziennego (Goffman, 2000, s. 5). Człowiek na co dzień podejmuje się odgrywania różnych ról, co implikuje korzystanie ze związanych $\mathrm{z}$ nimi zestawów zachowania, które muszą być dobrane odpowiednio do sytuacji. Jedną z dziedzin, w których zachodzi ten proces, jest polityka. Każde działanie polityczne jest częścią większego przedstawienia, które ma za zadanie wywołać określone reakcje u odbiorcy. Na scenie politycznej nie ma miejsca na spontaniczność, swobodę i bycie sobą. Ważne jest, aby działanie przekładało się na końcowe wyniki wyborcze.

Największą batalią polityczną są wybory. Jest to spektakl pełen strategii, emocji, pojedynczych bitew, zakończony wyłonieniem zwycięzców oraz przegranych. To właśnie debaty kandydatów, wiece polityczne, spoty wyborcze i decyzje podjęte w tym kluczowym czasie najlepiej pokazują, jaki scenariusz przyjęli politycy oraz jakie role konsekwentnie odgrywają. Oczywiście stopień zaangażowania i osobistych umiejętności każdego z nich jest inny. Scena polityczna w tym czasie do złudzenia przypomina scenę teatralną - miejsca spotkań wyborczych to przede wszystkim środki masowego przekazu, które zastępują deski teatralne. 


\section{WIELOŚĆ RÓL SPOŁECZNYCH W ŻYCIU KANYDATÓW}

Zgodnie z koncepcją E. Goffmana (2000) każda osoba pełni zdecydowanie więcej niż tylko jedną rolę społeczną (tamże). Można jednocześnie być matką, żoną, pracownikiem biura, jak i członkiem klubu fitness. W każdym przypadku wymagane są od człowieka inne zachowania werbalne i niewerbalne, różne stopnie formalności, a nawet słownictwo. Odgrywając niektóre role, ludzie zachowują się spontanicznie, a do innych starannie się przygotowują. Rola kandydata w wyborach jest o tyle ciekawa, że realizowane w jej ramach działania są z góry założone i perfekcyjnie przemyślane. Nie ma w niej miejsca na spontaniczność. Polityk startujący w kampanii wyborczej musi posiadać program wyborczy, wiedzieć, jak go przedstawić, jak siebie zaprezentować, aby w oczach wyborców wypaść jak najlepiej, mieć świadomość, do kogo chce trafić swoim przekazem. Uogólniając, staje się towarem, który w jak najlepszym wydaniu należy sprzedać nie komu innemu, jak właśnie wyborcy.

\section{Kreowanie Wizerunku polityka}

Wygrane wybory to cel każdej partii politycznej, jak i poszczególnych polityków niezależnie od specyfiki ustroju politycznego czy kultury danego kraju. Postulaty wyborcze, program oraz przynależność do określonego nurtu politycznego, takiego jak prawicowy, lewicowy czy liberalny, są kluczowym narzędziem wyborczym, lecz niejedynym. Istnieje również wiedza z obszaru politologii, jak również socjologii, marketingu i psychologii społecznej dotycząca kreowania wizerunku politycznego. Skupia się ona zarówno na tym, co w swoim przekazie uwzględnia polityk, a czego oczekuje społeczeństwo, jak i na tym, jak dany przekaz jest „opakowany”. Oznacza to, że można dopasować zachowanie, wygląd, sposób prezentacji danej osoby do oczekiwań wybranej grupy społecznej i poprzez wykorzystanie określonych technik marketingu politycznego wywrzeć oczekiwane wrażenie. Nawiązując do teorii E. Goffmana, można założyć, że polityk przygotowuje się do występu, mając wiedzę o tym, co widownia chciałaby zobaczyć. Program wyborczy będzie poniekąd scenariuszem, który aktor będzie wykorzystywał podczas spektaklu. Profesjonalnym doradztwem w powyższych kwestiach zajmują się doradcy medialni, tzw. spin doktorzy, którzy posiadają wiedzę niezbędną do 
uzyskania planowanych efektów. Pracę z tego rodzaju specjalistami, jak również działanie sztabów wyborczych można zakwalifikować do całej niewidocznej dla widowni części przedstawienia, jaką są kulisy. Przykładem osoby zajmującej się tego typu profesją na rynku polskim jest Piotr Tymochowicz, który odpowiadał za tworzenie lub zmianę wizerunku politycznego takich ludzi jak Marian Krzaklewski, Michał Kamiński, Stanisław Tymiński czy Andrzej Lepper. Jest on również, wraz z Marcelem Łozińskim, współtwórcą filmu pt. Jak to się robi z 2006 r., który obrazuje mechanizmy marketingu politycznego. Autorzy ukazują w nim, jak zwykłemu człowiekowi można przypisać oczekiwany wizerunek polityka.

Program wyborczy jest scenariuszem odgrywanej roli, ale ważne są również sposoby jego prezentacji. Aktorzy mogą wykorzystywać różne techniki, za pomocą których przedstawią określone treści. Na czym dokładnie polega marketing polityczny i jakie są jego narzędzia, można zrozumieć m.in. dzięki publikacji Wojciecha Cwaliny i Andrzeja Falkowskiego pt. Marketing polityczny: perspektywa psychologiczna. Według autorów polityk musi być przede wszystkim atrakcyjny i wiarygodny. Jego przekaz powinien być kompetentny, czyli opierać się na sprawdzonych i rzetelnych informacjach. Ważne jest, aby komunikacja odbywała się za pomocą języka potocznego, co umożliwia zrozumienie treści przez dużą liczbę odbiorców. Jeżeli politycy używaliby zbyt specjalistycznych terminów i skomplikowanych opisów, znaczna część społeczeństwa nie rozumiałaby, co próbują przekazać, a jak wiadomo, ludzie lubią to, co znane i zrozumiałe. Wiarygodność mówcy sprawia, że wyborca nabiera zaufania do wygłaszanych tez, a w niektórych przypadkach polityk zyskuje autorytet. Dzięki temu dużo łatwiej przekona osoby niezdecydowane swojego punktu widzenia. Dodatkowo odbiorcy łatwiej zaakceptują poglądy polityka na określone tematy, jeżeli w innych aspektach również się z nim zgadzają.

Ważną kwestią z obszaru marketingu politycznego są cechy przekazu. Znając podstawowe przesłanki, jesteśmy w stanie przygotować komunikat, który lepiej zapadnie w pamięć odbiorcy. Kolejność prezentacji informacji znacząco wpływa na to, jak zostanie zapamiętana jego treść. Mowa tu o efekcie pierwszeństwa i efekcie świeżości. Ludzie znacznie lepiej przyswajają komunikaty, które są przygotowane za pomocą odpowiednich technik, dzięki 
czemu wpływają na sposób ich odbioru. Wiadomości zawierające wnioski są lepiej zapamiętywane. Marketing polityczny jest szczególnie istotny w przypadku wywierania wpływu na wyborców niezdecydowanych.

Do ukazania kontekstu socjologicznego założeń marketingu politycznego wybrałam teorię dramaturgiczną E. Goffmana. Zakłada ona znacznie szerszy zakres zjawisk społecznych i zachowań ludzkich niż tylko polityka, ale można ją również zredukować do wybranego aspektu życia jednostki. Dzięki niej scenę polityczną możemy zobrazować jako wybrany spektakl. Działają w nim ścisłe reguły i zależności. Polityk jest aktorem, który odgrywa określoną rolę. Ma do dyspozycji wachlarz zachowań przypisanych do swojej roli i posługuje się wcześniej ustalonym scenariuszem. Może używać rekwizytów, jak również dopasowywać do swojej roli wygląd i ubiór. Celem jest stworzenie odpowiedniego wrażenia na publiczności. Przenosząc to na realną scenę życia politycznego - tak właśnie się dzieje. Politycy ubierają się zgodnie z oczekiwaniami wyborców, według tzw. dress code’u. Zdecydowana większość mężczyzn wybiera strój formalny, tzn. garnitur, koszulę i krawat, a kobiety - garsonkę. Efektem jest wygląd elegancki, lecz klasyczny...

Kolejnym przykładem dopasowania zachowań do wybranej roli jest to, jakich słów używają politycy. Wśród najlepiej odbieranych społecznie wyrazów są: wolność, rozwój, demokracja, sprawiedliwość. Dzięki nim polityk wywiera na rozmówcach pozytywne wrażenie. Nie jest również obojętna jego postawa, gestykulacja czy intonacja głosu. Dzięki złączeniu palców obu rąk na kształt piramidy mówca sprawia wrażenie bardziej kompetentnego. Otwieranie ramion natomiast i ukazywanie wierzchu dłoni mówi o otwartości i szczerości. Przykładem postawy odbieranej negatywnie są skrzyżowane ręce i przygarbiona postawa. Polityk powinien mówić nie za szybko, lecz energicznie i z dużą pewnością siebie. Nie może ukazywać publiczności swojego wahania bądź braku wiedzy. Mowa ciała jest silnym narzędziem tworzenia wizerunku i dzięki wiedzy z jej zakresu można odegrać założoną rolę. Atrybutami polityka, poza strojem, mogą być odpowiednio dobrane dodatki, takie jak okulary, teczka lub w przypadku kobiety: torebka, zegarek i biżuteria. Ważna jest odpowiednia, stonowana fryzura lub schludny makijaż u kobiet występujących na scenie politycznej. Kolor dobranych ubrań również posiada określone znaczenie. Mężczyźni najczęściej wybierają koszule w odcieniach 
niebieskiego i białego. Dobierane do nich krawaty są raczej w stonowanej kolorystyce, ale oczywiście są wyjątki. Krzykliwe kolory, takie jak czerwień, mogą przyciągnąć uwagę bądź nawet stać się znakiem rozpoznawczym, jak w przypadku słynnego krawata członka Samoobrony, Andrzeja Leppera. Jednak większość polityków stawia na styl zwany klasyczną elegancją, ponieważ jest on najlepiej odbierany społecznie.

\section{ANALIZA WYBRANYCH NARZĘDZI KREOWANIA WIZERUNKU NA PRZYKŁADZIE KANDYDATÓW RAFALA TRZASKOWSKIEGO I PATRYKA JAKIEGO}

Praktycznym przykładem wykorzystania zabiegów marketingu politycznego są działania sztabów oraz samych kandydatów przed wyborami. W artykule przeprowadzona zostanie analiza wybranych aspektów związanych ze strategią przed wyborami samorządowymi w Warszawie. Artykuł skupiać się będzie na działaniach dwóch kandydatów starających się o urząd prezydenta Warszawy, a należących do największych i opozycyjnych względem siebie partii politycznych w Polsce - Patryka Jakiego i Rafała Trzaskowskiego. W sierpniu 2018 r. premier Mateusz Morawiecki ogłosił, że wybory odbędą się 21 października, czyli tego dnia kampania oficjalnie ruszyła. Prawdą jednak jest, że działania promujące kandydatów rozpoczęły się znacznie wcześniej, by w jak największym stopniu uzyskać efekt pierwszeństwa. Obaj kandydaci posiadają już określony dorobek w działalności politycznej. Poniżej zostaną przedstawione pokrótce ich życiorysy w celu ukazania ich wcześniejszego związku z polityką.

Rafał Kazimierz Trzaskowski, urodzony 17 stycznia 1972 r. w Warszawie, jest synem pianisty i kompozytora Andrzeja Trzaskowskiego. Z wykształcenia politolog, uzyskał również stopień doktora nauk humanistycznych w zakresie nauk o polityce na Uniwersytecie Warszawskim na podstawie pracy pt. Dynamika reformy instytucjonalnej w Unii Europejskiej. Jego kariera zawodowa związana była i jest z polityką. W latach 2000-2001 był zatrudniony jako sekretarz Komitetu Integracji Europejskiej u Jacka Saryusza-Wolskiego. W okresie między 2004 a 2009 r. związał się z Platformą Obywatelską (PO) i z jej ramienia piastował stanowisko doradcy delegacji PO w Parlamencie 
Europejskim. W 2009 r. zdobył mandat eurodeputowanego w okręgu warszawskim. Podczas kampanii wyborczej uzyskał wsparcie osób takich jak Michał Żebrowski, Tomasz Karolak i Urszula Dudziak, co zostało wykorzystane w jego negatywnej kampanii podczas wyborów samorządowych w 2018 r. W roku 2010 przewodził sztabowi wyborczemu Hanny Gronkiewicz-Waltz na urząd prezydenta Warszawy. Sprawował również funkcję ministra administracji i cyfryzacji (w 2013 r.). W 2015 r. uzyskał mandat posła na Sejm VIII kadencji, a w następnie został wybrany na stanowisko wiceprzewodniczącego Komisji ds. Unii Europejskiej ${ }^{1}$.

Drugi kandydat, Patryk Tomasz Jaki, urodził się 11 maja 1985 r. w Opolu i jest synem Ireneusza Jakiego, również polityka². Jest zdecydowanie młodszy od swojego rywala i nie pochodzi z Warszawy, co oczywiście nie musi się przekładać na sondaże, ale zostaje wykorzystane w zabiegach marketingu politycznego przez sztaby wyborcze obu kandydatów. Kandydat Zjednoczonej Prawicy jest absolwentem politologii na Uniwersytecie Wrocławskim (2010 r.). Uczęszczał do IESE Business School w Barcelonie, którą ukończył w 2018 r. Był członkiem Forum Młodych Prawa i Sprawiedliwości (PiS), do którego przystąpił w 2003 r. Piastował stanowisko specjalisty ds. marketingu w Międzynarodowej Wyższej Szkole Logistyki i Transpor$t^{3}$. Był asystentem Ryszarda Legutki, ówczesnego eurodeputowanego, oraz członkiem gabinetu politycznego wojewody opolskiego (tamże). W $2006 \mathrm{r}$. związał się z Platformą Obywatelską i został radnym miasta Opole. Zaraz po wyborach opuścił to ugrupowanie i ponownie rozpoczął współpracę z PiS-em. Po czterech latach został powtórnie wybrany na stanowisko radnego i został przewodniczącym klubu radnych PiS-u. W 2011 r. został posłem na Sejm VII kadencji, w tym czasie objął również stanowisko rzecznika prasowego w Solidarnej Polsce. Został ponownie wybrany do parlamentu w 2015 r., 18 listopada uzyskał też stanowisko sekretarza stanu w Ministerstwie Sprawiedliwości (tamże). Z jego inicjatywy powstała Komisja Weryfikacyjna ds. Reprywatyzacji, której został przewodniczącym 11 maja 2017 r. W międzyczasie był zaangażowany m.in. w tworzenie Muzeum Żołnierzy Wyklętych i Więźniów Politycznych PRL, w zmiany w ustawodawstwie dotyczącym odbierania rodzicom dzieci ze względu na złą sytuację materialną czy w projekt readaptacji i pomocy więźniom. 
Jak pokazują krótkie życiorysy zawodowe obu kandydatów, posiadają oni duże doświadczenie w działaniach politycznych i są obecni na scenie politycznej od lat. Jednak nie przekłada się to na ich równą rozpoznawalność wśród potencjalnych wyborców. Według sondażu Wirtualnej Polski z dni 20-24 kwietnia 2018 r. jedynie 34\% badanych zna kandydata PO. Zdecydowanie bardziej znany jest P. Jaki, którego kojarzy 59\% ankietowanych ${ }^{4}$. W tym samym badaniu zadano pytanie: „Kto Twoim zdaniem wygra pierwszą turę wyborów prezydenckich w Warszawie?". W tym wypadku 23\% respondentów oddałoby głos na Jakiego, a 16\% na Trzaskowskiego. Może być to spowodowane zarówno dużą aktywnością Jakiego na scenie politycznej Polski w ostatnich latach, jak i częstymi wystąpieniami medialnymi, w szczególności w Komisji Weryfikacyjnej ds. Reprywatyzacji, której prace były transmitowane na żywo w TVP Info. W tym badaniu widoczny jest efekt świeżości omawiany we wcześniejszej części artykułu. R. Trzaskowski zdecydowanie rzadziej występował $\mathrm{w}$ telewizji i związany był z działalnością Polski w Unii Europejskiej, która cieszy się zdecydowanie mniejszym zainteresowaniem obywateli niż krajowa scena polityczna.

Sondaże to jeden $\mathrm{z}$ elementów marketingu politycznego. Obserwując poszczególne media, można zauważyć, że badania opinii wykonywane w podobnym okresie dają zdecydowanie różne wyniki. Media sympatyzujące z PiS-em, takie jak telewizja publiczna, gazety „Do Rzeczy”, „W Sieci” czy "Gazeta Polska”, ukazują inne spojrzenie na poszczególne zdarzenia, szczegóły z życia kandydatów, sondaże oraz interpretacje wypowiedzi niż media sympatyzujące z obozem PO, takie jak TVN, „Gazeta Wyborcza” czy „Polityka”. Należy pamiętać również o bardzo istotnym źródle przekazu współczesnych czasów, jakim jest Internet, w którym również widoczne są sympatie i antypatie wyborcze. Na przykład na stronie wpolityce.pl znajdziemy zdecydowanie prorządowe artykuły, a na stronie gazeta.pl te krytyczne względem obecnej władzy. Przyglądając się z bliska temu zjawisku, P. Jaki otrzymałby w połowie sierpnia 2018 r. poparcie 39\%, zaś R. Trzaskowski $40 \%$ według sondażu opublikowanego w „Do Rzeczy”. Telewizyjne „Fakty” natomiast przedstawily wyniki badań Kantar Millward Brown, w których kandydat PiS-u uzyskałby 33\%, a kandydat PO 37\% ${ }^{5}$. Jak widać, sondaże są różne, ale cel jeden - przedstawienie preferowanego kandyda- 
ta w świetle jak największego poparcia i zaprezentowanie wyborcom jego politycznej siły. To może wpłynąć na głos osób niezdecydowanych, a o to przede wszystkim chodzi. Wyborcy, którzy nie podjęli jeszcze decyzji, są największym potencjałem dla sztabów wyborczych. Ludzie zdecydowanie wolą trzymać ze zwycięzcami niż z przegranymi, dlatego takie sondaże mogą mieć wpływ na ich końcową decyzję.

Kolejnym narzędziem kreowania wizerunku w rozpatrywanych wyborach jest częstość ukazywania się kandydata w mediach. Zjawisko to było już wcześniej opisywane przy omawianiu rozpoznawalności, ale istotne jest dodanie kilku szczegółów w kontekście budowania wizerunku zwycięzcy. Dobrym przykładem tego zabiegu jest działalność P. Jakiego w Komisji Weryfikacyjnej ds. Reprywatyzacji. Kandydat PiS-u był przewodniczącym tej komisji. Jej posiedzenia odbywały się często, były transmitowane na żywo w TVP Info, a główne aspekty, afery i sukcesy były pokazywane w głównym wydaniu „Wiadomości”, które mają dużą oglądalność. Jaki był w Komisji bardzo aktywny, odnosił sukcesy i ukazywał nieprawidłowości rządów partii opozycyjnej. Dzięki temu może pokazać wyborcom, że mimo iż nie jest rodowitym warszawiakiem, to angażuje się w życie Warszawy, jest zaznajomiony z jej problemami i chce poprawy jakości życia codziennego jej mieszkańców. Jego działalność, niezależnie od kampanii politycznej, wpływa również na efekt świeżości u widzów, ponieważ widzieli go często i dzięki temu lepiej zapamiętywali. Dla porównania, R. Trzaskowski bardzo często występował w telewizji TVN i był gościem m.in. „Faktów po faktach”. W swoich wypowiedziach stanowczo odcinał się od przyrównywania go do Bronisława Komorowskiego. Ostatnie dwa tygodnie kampanii w dużej mierze poświęcił na spotkania z mieszkańcami. Dobrze promowana we wspomnianych mediach idea „18 dzielnic i jednej Warszawy” i lokalnej współpracy sprawiła, że polityk wypadł w oczach wyborców profesjonalnie i aktywnie ${ }^{7}$.

Szczegóły z życia kandydatów to również element gry politycznej, który w tej kampanii był często wykorzystywany. Trzaskowskiemu wypomina się, że podczas kampanii był niestabilny i niewiarygodny, zmieniając miasta, z którymi jest związany. W kampanii do parlamentu w 2015 r. kandydował z list krakowskich, informując wyborców tego miasta, że spędza w nim każdą wolną chwilę ${ }^{8}$. W kampanii samorządowej 2018 r. ukazywał, 
jak mocno związany jest z Warszawą jako rdzenny warszawiak. Natomiast Jakiemu opozycja wypomina, że nie jest on rodowitym mieszkańcem stolicy i jej problemy są mu obce. Obaj kandydaci starali się pokazać, jak bardzo zaangażowani są w życie Warszawy. Siedem krzeseł dzieliło ich od siebie podczas uroczystości związanych z 74. rocznicą powstania warszawskiego 9 . Pojawiali się na uroczystościach $\mathrm{w}$ jednym czasie, ale pozostawali w określonej odległości od siebie.

Jeżeli chodzi o narzędzia z obszaru czarnego PR-u, to również w tej kampanii można było znaleźć jego elementy. Chodzi tu przede wszystkim o wyciąganie faktów z życia osobistego kandydatów, ich przeszłości, niekiedy $\mathrm{w}$ zniekształconym obrazie i interpretacji w celu ośmieszenia lub zdeprecjonowania polityka. P. Jakiemu wypominano m.in. jego zdjęcie $\mathrm{z}$ lat młodości, przedstawiające młodego chłopaka siedzącego pod blokiem, ubranego $\mathrm{w}$ dres i w niczym nieprzypominającego odpowiedzialnego polityka ${ }^{10}$. Miało to na celu ukazanie młodego wieku kandydata i jego braku profesjonalizmu. R. Trzaskowskiemu wypomniano spoty wyborcze z udziałem Michała Żebrowskiego, w których nie byłoby nic niezwykłego, gdyby nie scenariusz i kontekst nagrania. Aktor wystylizowany jest w nim na kogoś, kto ma odbyć wyrok śmierci (związane ręce i oczy) i krzyczy w nim „za Rafała”, co odbierane jest przez wielu za niestosowne i w złym guście ${ }^{11}$.

$\mathrm{Na}$ spotkaniach z udziałem kandydata PiS-u pojawiają się członkowie Komitetu Obrony Demokracji i Obywateli RP, demonstrując swój sprzeciw wobec polityka. W tym wypadku panuje równowaga czarnego PR-u obu frakcji, ponieważ na spotkania z Trzaskowskim przychodzili zwolennicy Jakiego, burząc jego wzorcowy przekaz. Obaj kandydaci prześcigają się w składaniu obietnic wyborczych, poczynając od budowy kolejnych linii metra, co jest klasyczną metodą marchewki i kija. Rywalizujący politycy zdecydowali się na oddolną kampanię wyborczą, w której stawiają na częsty kontakt z wyborcami. Trafny okazał się projekt i jego chwytliwa nazwa „18 dzielnic w 18 godzin”, w ramach którego R. Trzaskowski objeżdżał Warszawę, pokazując, że należy zarządzać nie tylko z poziomu ratusza, ale również ulicy. Dzięki takim hasłom wyborcy zdecydowanie lepiej zapamiętują działania i kampanię polityka. Sam pomysł wyjścia do mieszkańców Warszawy i skierowanie uwagi na ich życie codzienne sprawił, że Trzaskowski ocieplił znacząco swój wizerunek. 


\section{STRÓJ I GESTYKULACJA}

Mowa niewerbalna jest niezwykle ważnym elementem wywierania wpływu na odbiorcę. Podczas wyborów samorządowych na urząd prezydenta Warszawy obaj kandydaci starali się ukazać jako osoby dostępne i aktywne społecznie. Sztaby wyborcze i kandydaci postawili na stworzenie wrażenia, że są takimi samymi ludźmi jak wyborcy, co miało służyć wywołaniu uczucia mniejszego dystansu społecznego. R. Trzaskowski często występował na wiecach w garniturze bez krawata bądź marynarki. Na spotkania $\mathrm{z}$ wyborcami najczęściej wybierał ubrania w odcieniach niebieskiego, który wywołuje wrażenie powagi, spokoju i wrażliwości ${ }^{12}$. Jego ubiór był schludny, elegancki, ale nie można było określić go formalnym. W tym okresie posiadał nienaganną fryzurę oraz lekki zarost. Występując, starał się często uśmiechać, a wręcz śmiać ${ }^{13}$. Można było zauważyć, że wypowiadając się, często gestykulował, co miało na celu wzmocnienie przekazu. Zdarzało mu się również składać palce w znak zwycięstwa, co również miało za zadanie umocnić jego wizerunek jako osoby odnoszącej sukcesy. Wszystko to wpływało na ocieplenie jego wizerunku w oczach wyborców.

P. Jaki podczas kampanii starał się sprawiać wrażenie osoby dostępnej i bliskiej zwykłym ludziom w sposób zbliżony do Trzaskowskiego. Jego stroje, podobnie jak u jego kontrkandydata, były eleganckie, ale nieprzesadnie formalne. $Z$ racji swojej dużej aktywności podczas prac Komisji ds. Reprywatyzacji wybierał przede wszystkim klasyczny garnitur, zazwyczaj w odcieniach granatu. Ma to znaczenie, ponieważ prace Komisji często transmitowane były w telewizji. Jednak podczas kampanii często nosił mniej oczywiste kreacje. Marynarki w kratkę w różnych odcieniach, szelki, krawaty w kolorze brązu - to tylko niektóre z elementów garderoby polityka, które uważniejszy obserwator mógł zapamiętać. Pojawił się także głos krytyki odnośnie do ubioru polityka zarzucający mu brak umiejętności dopasowania części garderoby ${ }^{14}$. Należy pamiętać, że nawet nieprzychylne opinie mogą zadziałać na korzyść osoby medialnej, wpływając na lepsze zapamiętanie jej przez odbiorcę. Można stwierdzić, że stroje Jakiego były odważniejsze i mniej klasyczne niż jego kontrkandydata. Obaj panowie mieli zadbane fryzury i delikatny zarost. Patryk Jaki podczas swoich przemówień często aktywnie gestykulował, podkreślając słowa mową niewerbalną. 


\section{KAMPANIA POLITYCZNA W MEDIACH SPOŁECZNOŚCIOWYCH}

Bardzo istotnym elementem kampanii wyborczej jest działanie i obecność kandydatów w mediach społecznościowych, z których korzysta wielu potencjalnych wyborców. Obaj kandydaci odznaczali się dużą aktywnością, wykorzystując takie media jak Facebook czy Twitter. Można prześledzić w nich ich kampanie wyborcze z uwzględnieniem wieców wyborczych, wywiadów, spotkań z wyborcami. W mediach społecznościowych pojawiły się również materiały istotne w kampanii wyborczej, takie jak spoty wyborcze lub plakaty, zdjęcia kandydatów. Politycy mogli również podzielić się swoją opinią i komentarzem na każdy temat bez limitu czasu i ilości przekazywanej treści. W tygodniku „Newsweek” Paweł Matuszewski dokonał analizy aktywności obu kandydatów w Internecie. Jeżeli chodzi o portal społecznościowy Facebook, to zdecydowaną przewagę miał Jaki, o którym wspomniano aż 550 tys. razy. Trzaskowski posiadał takich wyświetleń 160 tys. Polityk PiS-u sprawniej też zarządzał swoim profilem, motywując użytkowników do aktywności, takiej jak: udostępnienie postu, polubienie czy komentowanie. Czyniło tak dwa razy więcej internautów niż w przypadku jego rywala. Z kolei działalność na portalu Twitter jest bardziej wyrównana. Jakiego obserwowało tam 200 tys. użytkowników, natomiast Trzaskowskiego 150 tys. osób. Tweety jednego i drugiego kandydata były lubiane przez ok. 250 użytkowników i przekazywane kolejnej osobie przez 60 użytkowników ${ }^{15}$.

\section{POLITYK JAKO AKTOR W TEATRZE ŻYCIA CODZIENNEGO}

Porównując kampanię do teatru, należy wyróżnić podstawowe obszary działań i zachowania aktorów, którzy w tym przypadku są politykami. Pierwszym miejscem, o którym warto wspomnieć, są kulisy, za którymi artyści szykują się do występu. W tym wypadku są to sztaby wyborcze obu kandydatów, przygotowujące ich do wystąpień publicznych. Opracowywane są programy wyborcze, pisane przemówienia, dobierany strój, określany wygląd kandydata i organizowane sceny, które w tym wypadku są miejscami 
publicznych wystąpień polityka. Podobnie jak w teatrze zwykli ludzie nie zaglądają za kulisy, tak i w przypadku kulisów politycznych omawianych kampanii można jedynie ogólnie zakreślić, jak taka praca mogła wyglądać i na czym polegała. Następnie aktorzy wychodzą na specjalnie przygotowaną scenę, pełną rekwizytów i dekoracji. W przypadku kampanii Jakiego i Trzaskowskiego sceną były miejsca związane z Warszawą, jej ulice, domy, miejsca ważne kulturowo. Za rekwizyty używane przez obu polityków możemy uznać mównicę, flagę Polski i Unii Europejskiej znajdujące się za kandydatami podczas wystąpień. Kolejnym elementem w omawianym teatrze jest osobista fasada aktora-polityka. Jak już wspomniano, obaj kandydaci ubierali się i wyglądali odpowiednio do odgrywanych ról. Ich stroje były eleganckie, dodatki typu zegarki czy teczki stosowne do miejsca i sytuacji.

W ujęciu teorii Goffmana, ukazującej życie jako teatr, publiczność kampanii wyborczej stanowili wszyscy obserwatorzy publicznych wystąpień obu kandydatów. Byli to zarówno widzowie telewizyjnych programów czy słuchacze radia, jak i uczestnicy wieców wyborczych. Każda osoba, do której trafiały informacje z kampanii wyborczej, stanowiła widownię. Dotarcie do publiczności odbywało się zarówno przez kontakt bezpośredni podczas wieców i spotkań z wyborcami, jak i pośredni - dzięki środkom masowego przekazu. Kandydaci mieli na celu pozyskanie głosów jak największej liczby wyborców niezdecydowanych. Należy pamiętać o istnieniu wielości ról społecznych - poza ukazywaniem siebie w roli przyszłego prezydenta Warszawy politycy pełnili również funkcje publiczne, które wpływały na ich wizerunek. P. Jaki przez okres kampanii był przewodniczącym Komisji ds. Reprywatyzacji i jego wystąpienia wielokrotnie były transmitowane w mediach publicznych. Podczas obrad przyjmował rolę przewodniczącego, co oznaczało, że zarządzał porządkiem prac Komisji, decydował o kluczowych sprawach związanych z organizacją jej obrad, zwracano się do niego, tytułując go przewodniczącym. W terminologii używanej w teorii E. Goffmana można użyć sformułowania, że polityk ubrał maskę przewodniczącego Komisji i wykonywał wszystkie funkcje przypisane do tej roli oraz zachowywał się zgodnie ze związanymi z nią oczekiwaniami. Ważne jest, aby aktor był wiarygodny i przekonywujący w swoich wystąpieniach. W tym przypadku rola przewodniczącego w Komisji była spójna i pasowała do roli kandydata w wyborach 
na urząd prezydenta Warszawy. Odgrywanie przez aktora w życiu wielu ról nie oznacza, że muszą one wzajemnie się wykluczać lub w jakikolwiek sposób przeszkadzać sobie nawzajem. Niektóre wręcz mogą wzmacniać wiarygodność innych, jak w opisanym przypadku.

\section{Podsumowanie}

Wyniki kampanii wyborczej poznaliśmy 23 października 2018 r. Rafał Trzaskowski otrzymał 56,67\% głosów, natomiast Patryk Jaki 28,53\%. Widać tu zdecydowane zwycięstwo Trzaskowskiego. Można stwierdzić, że kampania polityczna kandydata PO była wyrazista i lepiej utkwiła odbiorcom w pamięci. Warszawiacy wybrali polityka z większym stażem politycznym. $\mathrm{Na}$ przykładzie kampanii obu kandydatów można było zauważyć, jakimi narzędziami kreowania wizerunku posługiwali się zarówno politycy, jak ich sztaby wyborcze. Należy jednak pamiętać, że na preferencje wyborcze obywateli składają się różne kwestie, a kreowanie wizerunku jest tylko elementem, który może przeważyć szalę na rzecz jednego lub drugiego kandydata. Program wyborczy, jak również przynależność partyjna to podstawowe elementy, na podstawie których wyborca dokonuje procesu decyzyjnego.

Nawiązując do teorii dramaturgicznej E. Goffmana - widownię stanowią wszyscy obywatele przyglądający się kampanii wyborczej omawianych kandydatów. Scena polityczna w tym przypadku jest rozległa, ponieważ są nią miejsca, w których publicznie występują obaj politycy, np.: miejsca wieców, spotkań wyborczych, wywiadów czy wystąpień w parlamencie, a nawet Internet, gdzie pojawiają się ich wypowiedzi. Aktorami są obaj kandydaci, jak również ich najbliższe otoczenie, które zabiera głos w sprawie ich kampanii. P. Jaki i R. Trzaskowski byli dobrze przygotowani do odgrywanych ról. Zarówno w kwestii postulatów wyborczych, zachowania, wypowiedzi, jak i wyglądu. Dostosowywali swój przekaz do widowni, aby uzyskać jak najlepszy efekt dobrego odbioru komunikatu i zyskać potencjalnych wyborców. Nie można było perfekcyjnie odegrać swoich ról, ponieważ zawsze pojawiają się sytuacje nie do przewidzenia. Politycy jako ludzie popełniają błędy, a dodatkowo przeciwne sztaby wyborcze starają się utrudniać szlifowanie idealnego wizerunku kontrkandydata. 


\section{Bibliografia}

Cialdini, R. (2004). Wywieranie wplywu na ludzi: teoria i praktyka, Gdańsk: Wydawnictwo GWP. ISBN 8387957526.

Cwalina, W., Falkowski, A. (2005). Marketing polityczny: perspektywa psychologiczna, Gdańsk: Gdańskie Wydawnictwo Psychologiczne. ISBN 8389574764.

Ćwiklińska-Surdyk, D., Surdyk, A. (2013). Człowiek jako aktor na scenie życia. Teorie G.H. Meada i E. Goffmana a narracyjne gry fabularne, „Homo Ludens” nr 1, s. 45-61. ISSN 2080-4555.

Dobek-Ostrowska, B. (2005). Kampania wyborcza: marketingowe aspekty komunikowania politycznego, Wrocław: Wydawnictwo Uniwersytetu Wrocławskiego. ISBN 8322925905.

Giddens, A. (2012). Socjologia, Warszawa: Wydawnictwo Naukowe PWN. ISBN 9788301169565.

Griffin, E. (2003). Podstawy komunikacji społecznej, Gdańsk: Gdańskie Wydawnictwo Psychologiczne. ISBN 8389120143.

Goffman, E. (2000). Człowiek w teatrze życia codziennego, Warszawa: Wydawnictwo KR. ISBN 8386989777.

Goffman, E. (2006). Rytuat interakcyjny, Warszawa: Wydawnictwo Naukowe PWN. ISBN 9788301146818.

Hałas, E. (2007). Symbole i społeczeństwo: szkice z socjologii interpretacyjnej, Warszawa: Wydawnictwa Uniwersytetu Warszawskiego. ISBN 9788323503415.

Hałas, E. (2006), Interakcjonizm symboliczny. Społeczny kontekst znaczeń, Warszawa: Wydawnictwo Naukowe PWN. ISBN 9788301145903.

Heywood, A. (2009). Politologia, Warszawa: Wydawnictwo Naukowe PWN. ISBN 9788301147785.

Łebkowski, M. (2009), E-wizerunek. Internet jako narzędzie kreowania image’u w biznesie, Gliwice: Helion. ISBN 9788324621859.

Maciejowski, T. (2003). Narzędzia skutecznej promocji w Internecie, Kraków: Oficyna Ekonomiczna. ISBN 8388597892.

Mazur, M. (2002). Marketing polityczny: studium porównawcze prezydenckich kampanii wyborczych w USA i w Polsce, Warszawa: Wydawnictwo Naukowe PWN. ISBN 830113755X. 
McLuhan, M. (2004). Zrozumieć media: przedłużenia człowieka, Warszawa: Wydawnictwo Naukowo-Techniczne. ISBN 8320428955.

McQuail, D. (2007). Teoria komunikowania masowego, Warszawa: Wydawnictwo Naukowe PWN. ISBN 9788301151539.

Mrozowski, M. (2001). Media masowe: władza, rozrywka i biznes, Warszawa: Oficyna Wydawnicza Aspra-Jr. ISBN 8388766023.

Szacka, B. (2008). Wstęp do socjologii, Warszawa: Oficyna Naukowa. ISBN 9788374590617.

Turner, J. H. (2004a). Struktura teorii socjologicznej, Warszawa: Wydawnictwo Naukowe PWN. ISBN 8301140720.

Turner, J. H. (2004b). Socjologia. Koncepcja i ich zastosowanie, Warszawa: Wydawnictw Zysk i S-ka. ISBN 8371504594.

Ziółkowski, J. (2007). Socjotechnika autorytetu politycznego, Warszawa: Wydawnictwo ASPRA-JR. ISBN 9788375450934.

\section{Endnotes}

1) Pobrane z: https://www.trzaskowski.pl/o-mnie/ (dostęp: 30.08.2018).

2) Pobrane z: https://www.wprost.pl/tematy/10122767/patryk-jaki.html (dostęp: 30.08.2018).

3) Pobrane z: https://pl.wikipedia.org/wiki/Patryk_Jaki (dostęp: 20.08.2018).

4) Pobrane z: https://opinie.wp.pl/polacy-przekonani-ze-to-jaki-wygra-w-warszawienasze-badanie-6289579188872833a (dostęp: 2.09.2018).

5) Pobrane z: http://warszawa.wyborcza.pl/warszawa/7,54420,23808349,sondaz-trzaskowski-o-wlos-przed-jakim-kluczowa-druga-tura.html (dostęp: 30.08.2018).

6) Pobrane z: https://fakty.tvn24.pl/fakty-po-faktach,57/patryk-jaki-w-faktach-po-faktach,862483.html (dostęp: 30.07.2020).

7) Pobrane z: https://www.wirtualnemedia.pl/artykul/rafal-trzaskowski-prezydentemwarszawy-dlaczego-pokonal-patryka-jakiego (dostęp: 30.07.2020).

8) Pobrane z: https://www.tvp.info/37069642/dwie-twarze-trzaskowskiego-co-mowilo-krakowie-przed-i-po-wyborach (dostęp: 3.09.2018).

9) „W Sieci”, Za kulisami (pre)kampanii”, M. Fijołek, 6-12 sierpnia 2018 r. 
10) Pobrane z: https://dorzeczy.pl/kraj/45682/Portal-Agory-Jaki-w-mlodosci-stal-podblokiem-Fala-komentarzy.html (dostęp: 3.09.2018).

11) Pobrane z: https://wpolityce.pl/polityka/405990-zebrowski-tlumaczy-sie-z-klipu (dostęp: 3.09.2018).

12) Pobrane z: https://www.psychologiawygladu.pl/2015/05/symbolika-kolorow-w-zyciu-codziennym.html (dostęp: 20.08.2020).

13) Pobrane z: https://wyborcza.pl/7,82983,26074796,rafal-trzaskowski-final-kampaniiwyborczej-na-zywo.html (dostęp: 20.08.2020).

14) Pobrane z: https://www.polsatnews.pl/wiadomosc/2020-05-25/boniek-skrytykowalstroj-jakiego-europosel-odpowiedzial-grafika/ (dostęp: 20.08.2020).

15) Pobrane z: https://wiadomosci.wp.pl/jaki-bije-na-glowe-trzaskowskiego-walkaw-internecie-trwa-6270538271987841a (dostęp: 3.09.2018). 
